\title{
The enigma of DNA methylation in the mammalian oocyte
}

\section{[version 1; peer review: 4 approved]}

\author{
Hannah Demond1', Gavin Kelsey (iD1,2 \\ ${ }^{1}$ Epigenetics Programme, The Babraham Institute, Cambridge, UK \\ ${ }^{2}$ Centre for Trophoblast Research, University of Cambridge, Cambridge, UK
}

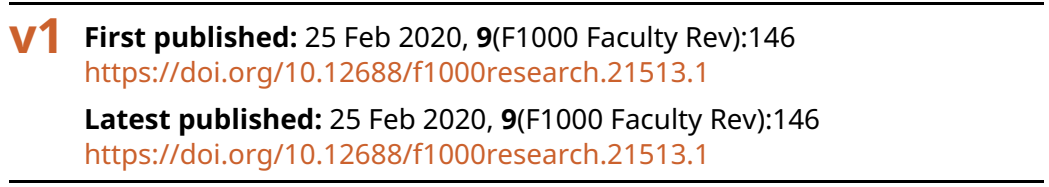

\section{Abstract}

The mammalian genome experiences profound setting and resetting of epigenetic patterns during the life-course. This is understood best for DNA methylation: the specification of germ cells, gametogenesis, and early embryo development are characterised by phases of widespread erasure and rewriting of methylation. While mitigating against intergenerational transmission of epigenetic information, these processes must also ensure correct genomic imprinting that depends on faithful and long-term memory of gamete-derived methylation states in the next generation. This underscores the importance of understanding the mechanisms of methylation programming in the germline. De novo methylation in the oocyte is of particular interest because of its intimate association with transcription, which results in a bimodal methylome unique amongst mammalian cells. Moreover, this methylation landscape is entirely set up in a non-dividing cell, making the oocyte a fascinating model system in which to explore mechanistic determinants of methylation. Here, we summarise current knowledge on the oocyte DNA methylome and how it is established, focussing on recent insights from knockout models in the mouse that explore the interplay between methylation and chromatin states. We also highlight some remaining paradoxes and enigmas, in particular the involvement of non-nuclear factors for correct de novo methylation.

Keywords

DNA methylation, oocyte, chromatin

\section{Open Peer Review}

\begin{tabular}{|c|c|c|c|c|}
\hline \multicolumn{5}{|c|}{ Approval Status $\checkmark \checkmark \checkmark \checkmark$} \\
\hline & 1 & 2 & 3 & 4 \\
\hline $\begin{array}{l}\text { version } 1 \\
25 \text { Feb } 2020\end{array}$ & $\checkmark$ & $\checkmark$ & $\checkmark$ & $\checkmark$ \\
\hline
\end{tabular}

Faculty Reviews are review articles written by the prestigious Members of Faculty Opinions. The articles are commissioned and peer reviewed before publication to ensure that the final, published version is comprehensive and accessible. The reviewers who approved the final version are listed with their names and affiliations.

1. Matthew Lorincz, Life Sciences Institute, University of British Columbia, Vancouver, Canada

2. Hiroyuki Sasaki, Medical Institute of Bioregulation, Kyushu University, Fukuoka, Japan

3. Taiping Chen, The University of Texas MD Anderson Cancer Center, Smithville, USA

4. Wei Xie, Tsinghua University, Beijing, China Any comments on the article can be found at the end of the article. 
Corresponding author: Gavin Kelsey (gavin.kelsey@babraham.ac.uk)

Author roles: Demond H: Writing - Original Draft Preparation, Writing - Review \& Editing; Kelsey G: Conceptualization, Writing Original Draft Preparation, Writing - Review \& Editing

Competing interests: No competing interests were disclosed.

Grant information: Work in GK's lab is supported by grants from the UK Medical Research Council (MRC; MR/S000437/1) and Biotechnology and Biological Sciences Research Council (BBSRC; BBS/E/B/000C0423). The funders had no role in study design, data collection and analysis, decision to publish, or preparation of the manuscript. The funders had no role in study design, data collection and analysis, decision to publish, or preparation of the manuscript.

Copyright: $\odot 2020$ Demond H and Kelsey G. This is an open access article distributed under the terms of the Creative Commons Attribution License, which permits unrestricted use, distribution, and reproduction in any medium, provided the original work is properly cited.

How to cite this article: Demond $\mathrm{H}$ and Kelsey $\mathrm{G}$. The enigma of DNA methylation in the mammalian oocyte [version 1; peer review: 4 approved] F1000Research 2020, 9(F1000 Faculty Rev):146 https://doi.org/10.12688/f1000research.21513.1

First published: 25 Feb 2020, 9(F1000 Faculty Rev):146 https://doi.org/10.12688/f1000research.21513.1 


\section{Mammalian oocytes have a distinctive epigenome}

DNA methylation is considered a repressive epigenetic modification. In most mammalian somatic cells, it occurs across the majority of the genome, with the notable exception of active gene regulatory elements, such as promoters, enhancers, and $\mathrm{CpG}$ islands that are generally unmethylated; methylation of such elements represses their activity ${ }^{1}$. Thus, DNA methylation is thought to function in the regulation of gene expression and in genome stability of heterochromatic regions. The oocyte is different in that both the genomic methylation pattern and its function are distinct from somatic cells. In oocytes, methylation is largely restricted to actively transcribed regions, including gene bodies, giving the oocyte genome a bimodal pattern of highly methylated gene bodies separated by intergenic or transcriptionally inactive regions with low levels of methylation ${ }^{2-4}$ (Figure 1). This simplified pattern might be a consequence of the fact that only a single de novo methyltransferase-DNA methyltransferase (DNMT) 3A-is active in oocytes ${ }^{5}$, but it also reflects that this is a newly acquired landscape, most pre-existing methylation having been erased. During mammalian embryo development, DNA methylation is globally erased in the primordial germ cells, which arise from cells of the epiblast. Thus, primary oocytes when they are first specified (which we can define as when a primordial germ cell enters and then arrests in the first meiotic prophase, in which state it remains until ovulation) are almost devoid of methylation ${ }^{2,5-7}$. DNA methylation is re-set during the later stages of oocyte growth, culminating in the oocyte-specific pattern. The oocyte therefore represents a fascinating model system to study DNA methylation mechanisms because an entire methylation landscape is established from scratch in a non-dividing cell. As much of our knowledge of the mechanisms and function of oocyte methylation has come from mouse models, we will focus mainly on the mouse in this review. For a comprehensive comparison between human and mouse oocyte methylation, see 8 .

The general restriction of methylation to actively transcribed gene bodies in the oocyte may indicate a distinct function. In somatic cells, gene-body methylation has been suggested to be one mechanism by which cryptic, intragenic promoters are repressed $^{9}$, although this conclusion has been questioned ${ }^{10}$. But methylation probably has little influence in controlling gene activity in the oocyte itself because primary oocytes appear to initiate a faithful transcription programme before DNA methylation is put in place ${ }^{11}$, and RNA-seq analysis of Dnmt $3 L$-knockout oocytes that are effectively devoid of methylation indicate that there are no transcriptional differences compared with control oocytes ${ }^{2}$. It might be that more careful analysis with improved RNA-seq methods could reveal some subtle effects. It is not evident, either, that methylation is required for repression of transposable element activity in oocytes. Where methylation in oocytes is absolutely essential for conferring DNA methylation is at imprinted genes. Imprinting
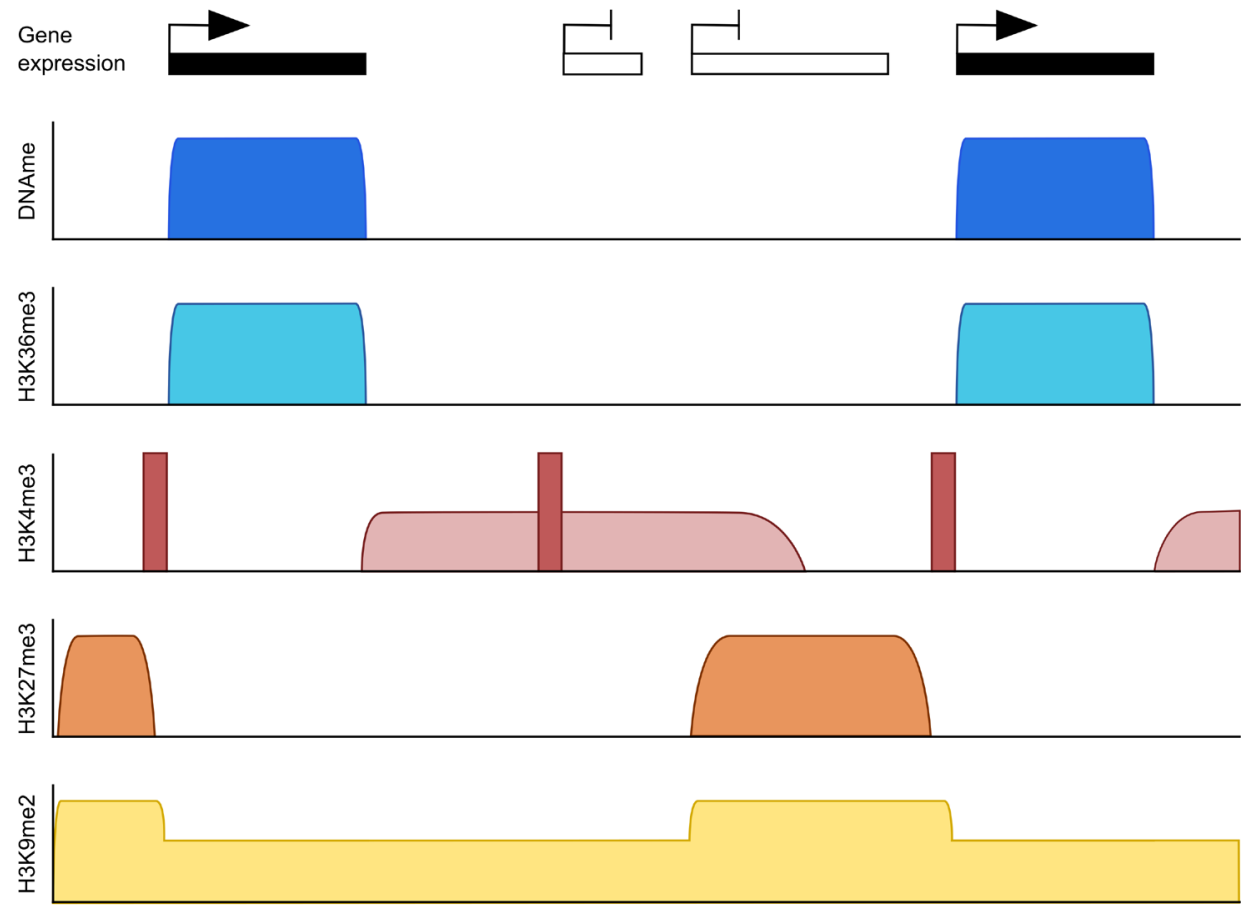

Figure 1. Schematic depicting the typical DNA methylation pattern of fully grown oocytes over active gene bodies and distribution of associated chromatin marks. While H3K36me3 is enriched over methylated domains, H3K27me3 and H3K9me2 are enriched in unmethylated domains. H3K4me3 has an unusual pattern in the oocyte in that peaks can be found at both active and inactive gene promoters (dark red) as well as enrichment over broad domains in untranscribed regions (light red). H3K27me3 is also broadly distributed over nontranscribed regions in oocytes but generally mutually exclusive to H3K4me3. 
is a process in which parent-of-origin allele-specific DNA methylation results in monoallelic expression of imprinted genes in offspring tissues ${ }^{12}$. Most imprinted genes in the mouse and human have their imprinting control regions (ICRs or germline differentially methylated regions [DMRs]) methylated in oocytes. These ICRs are $\mathrm{CpG}$ islands that are intragenic in oocytes and become methylated during oocyte growth ${ }^{4}$. Failure to establish methylation at ICRs in the oocyte results in severe developmental abnormalities ${ }^{13}$, showing the importance of correct epigenetic programming in the oocyte for the next generation.

It might seem extravagant to methylate a large fraction of the genome to ensure methylation of a couple of dozen imprinted loci. However, Dnmt3L- and Dnmt3a-null oocytes, which lack most DNA methylation, are ostensibly normal, can be fertilised, and will support development of the embryo until beyond implantation, when imprinting defects cause developmental $\operatorname{arrest}^{13,14}$ ). But it is possible that methylation in the oocyte has significance beyond classical imprinted genes. Embryos developing from DNA methylation-deficient oocytes succumb to problems in trophoblast development, hence placental defects, for which a contribution of genes outside known imprinted genes has been implicated ${ }^{15}$. Thus, it seems likely that there are more extensive effects of oocyte methylation than classical imprinted genes.

\section{De novo methylation requires active transcription}

Consistent with the predominant gene-body pattern of methylation, de novo DNA methylation in the oocyte has been shown to require active transcription. Knockout experiments in the mouse have shown that abrogating transcription across individual genes results in failure to establish methylation at these loci ${ }^{4,16-18}$. These examples focus on imprinted genes, whose imprinting status depends on the acquisition of DNA methylation at their ICRs. Similar conclusions have been drawn from human studies, in which chromosome deletions or rearrangements that are likely to result in interrupting transcription across imprinted domains lead to imprinting disorders ${ }^{19-21}$. This sets up the important premise that whether or not a gene is transcribed in oocytes can determine how it is regulated in the next generation.

Because of the predominant connection with transcription, species-specific variations in the oocyte transcriptome become reflected in variations in the oocyte methylome. A significant proportion of transcription units in oocytes have been found to be determined by alternative promoters ${ }^{4}$. Strikingly, more than a third of oocyte-specific transcription units initiate from active long-terminal repeats (LTRs) of endogenous retroviral elements, notably of the MaLR and endogenous retrovirus K (ERVK) classes $^{4,22,23}$. As LTR insertions differ between species, and even between strains of mice, the ensuing oocyte methylation patterns differ ${ }^{23}$. This variation can also provide the basis for differences in imprinted genes between human and mouse ${ }^{24}$.

\section{Mechanistic predictions of DNMT targeting}

There appears to be a simple logic to the methylation pattern that arises in oocytes, which is informed by the biochemical properties of the de novo methyltransferases involved: in mouse oocytes, this is DNMT3A as the active enzyme and the related DNMT3L as an essential auxiliary factor. Ablation of either in oocytes abolishes de novo methylation to similar degrees $^{2,5,6}$. Both proteins have limited DNA binding specificity; instead their binding and activity is modulated by the posttranslation modification state of histone proteins. Notably, both DNMT3A and DNMT3L bind the amino-terminal domain of histone $\mathrm{H} 3$ through their plant homeodomain (PHD)/ADD domains, but not when lysine 4 (H3K4) is methylated ${ }^{25}$. Recognition of unmethylated H3K4 releases DNMT3A from an autoinhibitory conformation ${ }^{26}$. In addition, the Pro-Trp-Trp-Pro motif (PWWP) domain of DNMT3A (there is no equivalent domain in DNMT3L) binds H3K36me2/3, at least in vitro ${ }^{27,28}$. DNMT3A may also interact with $\mathrm{H} 3 \mathrm{~K} 27 \mathrm{me} 3^{29,30}$, but this interaction does not apply to the isoform expressed in oocytes.

The antagonistic and permissive interactions of DNMT3A/ DNMT3L with $\mathrm{H} 3 \mathrm{~K} 4 \mathrm{me} 3$ and $\mathrm{H} 3 \mathrm{~K} 36 \mathrm{me} 3$, respectively, set up a simple scenario that could account for the gene-body methylation pattern characteristic of oocytes. H3K36me3 should be enriched over active gene bodies; H3K4me3 should demarcate active promoters and other $\mathrm{CpG}$ islands ${ }^{31}$. Intergenic or non-transcribing regions should have neither mark, such that these regions are neutral to the DNMT3A/DNMT3L complex. Chromatin immunoprecipitation and sequencing (ChIP-seq) profiles for mouse (and human) oocytes that have emerged in recent years can be interpreted largely to support this model: DNA methylation domains coincide with regions of H3K36me3 enrichment, and DNA methylation is absent from or much reduced in sites of $\mathrm{H} 3 \mathrm{~K} 4 \mathrm{me} 3$ enrichment $^{32-35}$ (Figure 1). Intriguingly, ChIP-seq data have revealed unusual properties of chromatin in mouse oocytes, in particular a widespread accumulation of $\mathrm{H} 3 \mathrm{~K} 4 \mathrm{me} 3$ over intergenic and low methylated domains $^{32-34}$.

\section{What have mouse knockout models told us?}

More definitive tests of the model above have come from gene knockouts in the mouse. H3K36me3 is conferred by a single, conserved enzyme, SETD2, which associates with the elongating RNA polymerase II, thus depositing H3K36me3 over transcribed gene bodies and recruiting the DNA methylation machinery (Figure 2A). CpG islands are normally depleted in H3K36me3, but during the course of oocyte growth, intragenic $\mathrm{CpG}$ islands destined for DNA methylation gain H3K36me3 enrichment ${ }^{36}$. Oocyte-specific ablation of SETD2 causes loss of H3K36me3 and, as expected, gene-body methylation is eliminated, as too is methylation of $\mathrm{ICRs}^{35}$. Rather surprisingly, however, there is appearance of DNA methylation in regions of the genome ordinarily unmethylated, as if DNMT3A/DNMT3L becomes more promiscuous in the absence of its favoured mark. It is possible that this off-target activity reflects the opportunity presented by the length of time over which de novo methylation can occur in oocytes, which may be several days during the latter stages of follicular development and oocyte growth.

Evidence for a role for active removal of H3K4 methylation first came with the knockout of lysine demethylase 1B (KDM1B) (AOF1), one of the two known H3K4me2 demethylases ${ }^{37}$. 


\section{Methylated regions}

A

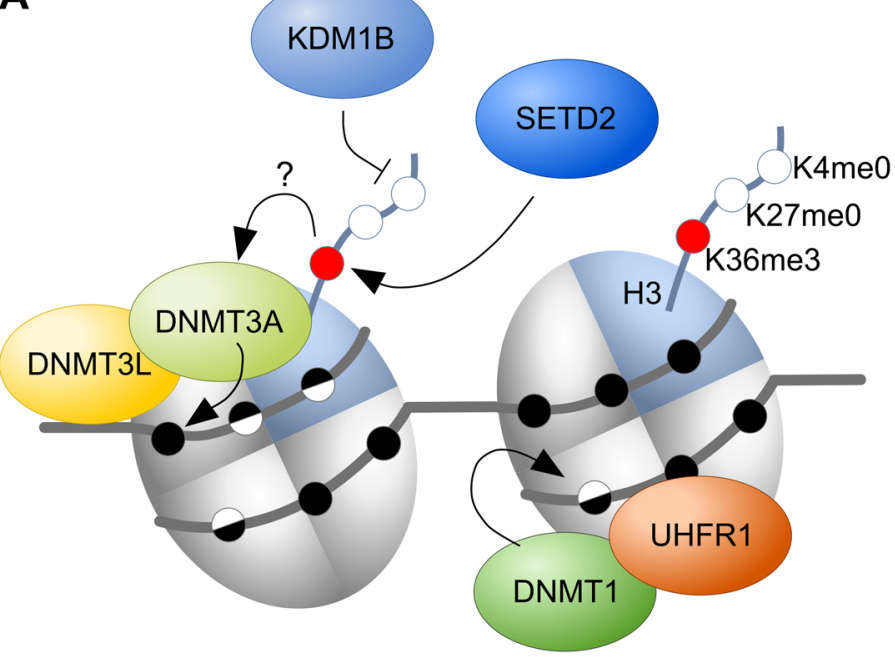

Transcribed gene bodies (high methylation)
B

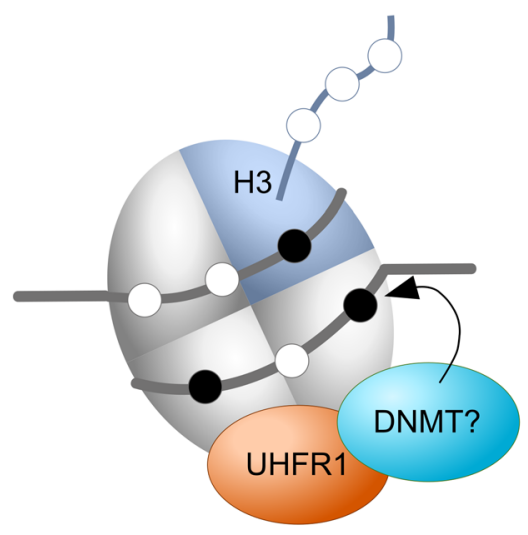

Intermediately methylated regions

\section{Unmethylated regions}

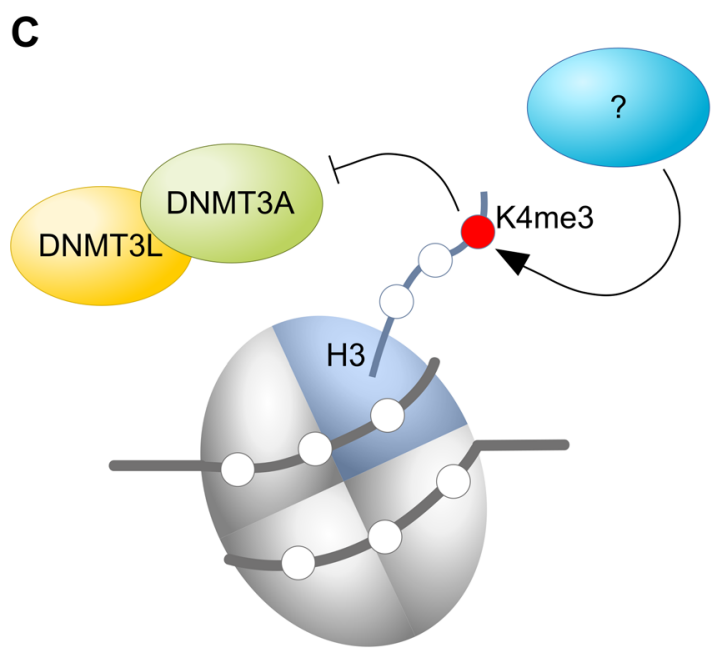

Active promoters

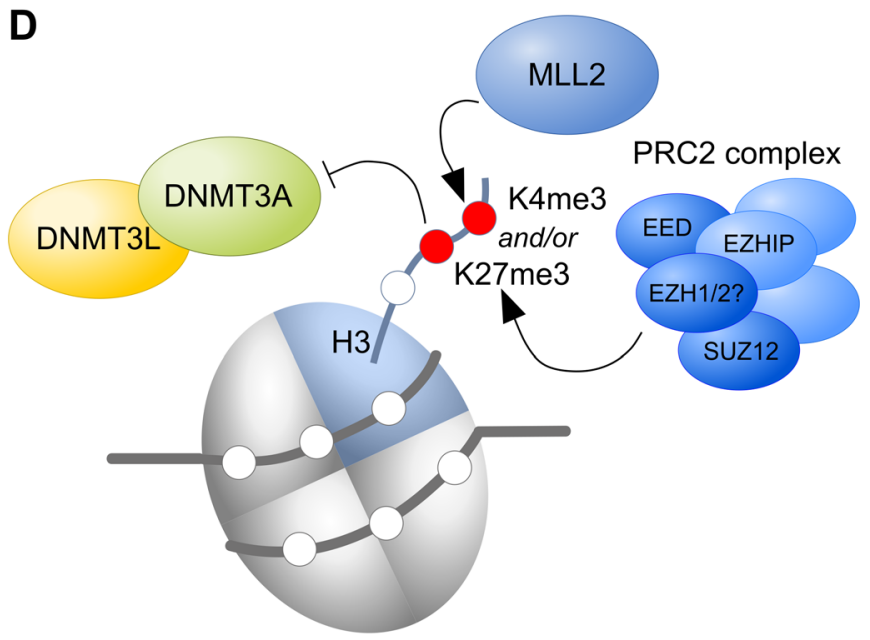

Transcriptionally inactive regions

Figure 2. Models showing chromatin factors involved in DNA methyltransferase (DNMT) 3A/DNMT3L recruitment in methylated regions and factors inhibiting DNMT3A/DNMT3L binding at unmethylated regions. A) At actively transcribed gene bodies, SETD2mediated H3K36me3 has been proposed to recruit DNMT3A/DNMT3L, whilst lysine demethylase 1B (KDM1B) seems to be required to prevent or remove histone 3 lysine 4 (H3K4) methylation. DNMT1 is needed for methylation of hemimethylated DNA. B) Ubiquitin-like, plant homeodomain and ring finger-containing 1 (UHRF1) is required for intermediate DNA methylation of some genic and intergenic regions, likely by recruiting one of the DNMT proteins, but the chromatin requirements are unknown. C) At active promoters, H3K4me3 is thought to prevent DNMT3A/DNMT3L binding. D) Transcriptionally inactive regions can be marked by mixed lineage leukaemia-2 protein (MLL2)mediated $\mathrm{H} 3 \mathrm{~K} 4 \mathrm{me} 3$ and/or polycomb repressive complex 2 (PRC2)-mediated H3K27me3, preventing recruitment of DNMT3A/DNMT3L to these regions. EED, embryonic ectoderm development; EZHIP, EZH inhibitory protein; SETD2, SET domain containing 2. 
Single-locus analysis indicated that some imprinted gDMRs failed to become methylated in $K d m l b$-null oocytes ${ }^{37}$. Subsequent genome-wide interrogation of methylation showed that most imprinted ICRs exhibit reduced methylation in $K d m 1 b$ knockout oocytes, as do many $\mathrm{CpG}$ islands that normally become methylated in oocytes ${ }^{36}$ (Figure 2A). Why some imprinted ICRs are more sensitive to the loss of KDM1B is not fully known, but there is some evidence that ICRs and $\mathrm{CpG}$ islands acquiring methylation later in oocyte growth are more susceptible 11,36,37. $^{10}$.

So far, there is no indication of a specific involvement of an $\mathrm{H} 3 \mathrm{~K} 4 \mathrm{me} 3$ demethylase for de novo DNA methylation, despite the expectation that $\mathrm{CpG}$ islands destined for DNA methylation are initially enriched in $\mathrm{H} 3 \mathrm{~K} 4 \mathrm{me} 3$ in primary oocytes ${ }^{36}$. Of the H3K4me3 demethylases, lysine demethylase 5C (KDM5C) (JARID1C) is the most abundantly expressed at the transcriptional level in mouse oocytes, but oocyte-specific ablation of KDM5C does not impair de novo DNA methylation (Huang and Kelsey, unpublished data). It is possible that the necessary removal of $\mathrm{H} 3 \mathrm{~K} 4 \mathrm{me} 3$ from $\mathrm{CpG}$ islands could be accomplished by nucleosome replacement as part of the transcription process. Ablation of the chaperone protein HIRA responsible for incorporation of $\mathrm{H} 3 / \mathrm{H} 4$ outside of DNA replication dramatically reduces DNA methylation ${ }^{38}$, which could attest to the contribution of nucleosome remodelling in de novo DNA methylation.

As noted above, oocyte chromatin is unusual in that $\mathrm{H} 3 \mathrm{~K} 4 \mathrm{me} 3$, which is normally highly localised to active promoters, accumulates over intergenic/non-transcribed domains during oocyte growth ${ }^{32-34}$ (Figure 1). Accordingly, there could be an expectation that this pervasive $\mathrm{H} 3 \mathrm{~K} 4 \mathrm{me} 3$ would constrain deposition of DNA methylation ${ }^{32}$, noting that $\mathrm{H} 3 \mathrm{~K} 4 \mathrm{me} 3$ and DNA methylation are accumulating in the oocyte genome with similar kinetics ${ }^{34}$. However, ablation of mixed lineage leukaemia-2 protein (MLL2/lysine methyltransferase 2B [KMT2B]), which is responsible for the bulk of intergenic $\mathrm{H} 3 \mathrm{~K} 4 \mathrm{me} 3$, results in very limited ectopic DNA methylation ${ }^{34}$. This result would tend to argue that absence of the antagonistic H3K4me3 modification is insufficient to promote genomic binding of DNMT3A/DNMT3L and recruitment depends more on an attractive mark, such as H3K36me3. In contrast, removal of DNA methylation from oocytes through ablation of DNMT3A results in further spreading of $\mathrm{H} 3 \mathrm{~K} 4 \mathrm{me} 3$ into ordinarily methylated domains, suggesting that genomic recruitment of MLL2 is predominantly determined by the availability of unmethylated CpG sites ${ }^{34}$.

Canonical $\mathrm{H} 3 \mathrm{~K} 4 \mathrm{me} 3$ is present at active promoters in the oocyte and thought to prevent DNA methylation at those sites (Figure 2C). Canonical H3K4me3 does not depend on MLL2, and the methyltransferase catalysing this mark is still unknown. Besides H3K4me3, H3K27me3 may also prevent DNMT3A/DNMT3L from methylating DNA, as H3K27me3 and DNA methylation are generally found to be mutually exclusive, including in oocytes (Figure 2D) ${ }^{39}$. Although mouse knockouts of members of the polycomb repressive complex 2 (PRC2), such as embryonic ectoderm development (EED) and the germcell-specific EZH inhibitory protein (EZHIP), have been described, so far they have not been evaluated for effects on DNA methylation in the oocyte $\mathrm{e}^{40-42}$.

The repressive modifications $\mathrm{H} 3 \mathrm{~K} 9 \mathrm{me} 2$ and $\mathrm{H} 3 \mathrm{~K} 9 \mathrm{me} 3$ have often been associated with DNA methylation. In the oocyte, $\mathrm{H} 3 \mathrm{~K} 9 \mathrm{me} 2$ is enriched in regions devoid of DNA methylation ${ }^{43}$. In line with this, ablating one of the major euchromatin $\mathrm{H} 3 \mathrm{~K} 9 \mathrm{me} 2$ methyltransferases, G9A/euchromatin histone methyltransferase 2 (EHMT2), has very limited impact on DNA methylation in oocytes ${ }^{43}$. Similar to other cell types, H3K9me3 in the oocyte is associated with DNA methylation and both marks can be found at silenced developmental genes ${ }^{44}$. However, there is no current evidence suggesting that de novo methylation depends on $\mathrm{H} 3 \mathrm{~K} 9 \mathrm{me} 3$. Instead, both $\mathrm{H} 3 \mathrm{~K} 9 \mathrm{me} 2$ and $\mathrm{H} 3 \mathrm{~K} 9 \mathrm{me} 3$ have been proposed to be involved in DNA methylation maintenance, as the DNMT1 accessory protein ubiquitin-like, PHD and ring finger-containing 1 (UHRF1) has a binding domain for $\mathrm{H} 3 \mathrm{~K} 9 \mathrm{me} 3^{45-48}$.

The precise timing and dependencies of the chromatin events required to ensure faithful DNA methylation are still not fully understood. For example, is a specific activity required to enable $\mathrm{H} 3 \mathrm{~K} 36 \mathrm{me} 3$ to accumulate at intragenic $\mathrm{CpG}$ islands, or is it accomplished by nucleosome turnover/replacement associated with transcription? The interdependence of many of the processes makes testing all elements of the model difficult. For example, earlier work in which transcription across the imprinted Zacl locus was ablated indicated that transcription was required for not only deposition of H3K36me3 but also removal of $\mathrm{H} 3 \mathrm{~K} 4 \mathrm{me} 2$ at the ICR-CpG island ${ }^{4}$. This could be interpreted as a requirement for transcription to recruit the $\mathrm{H} 3 \mathrm{~K} 4 \mathrm{me} 2$ demethylase $\mathrm{KDM} 1 \mathrm{~B}$, and, indeed, full methylation at this ICR does depend on $\mathrm{KDM}^{3} \mathrm{~B}^{36,37}$. But, from the Setd 2 knockout $^{35}$, it is also possible that ablation of H3K36me3 from the region leads to ectopic marking of H3K4me3 or H3K27me3 across the locus, which would be antagonistic to DNA methylation.

\section{Methylation independent of transcription}

We have focussed above on mechanisms that explain hypermethylated domains over gene bodies; however, a small fraction of the oocyte methylome falls outside of transcribed regions. Methylation of these regions depends on the DNMT1 accessory protein $\mathrm{UHRF}^{49}$, but the mechanism is not understood (Figure 2B). Correlation with chromatin maps may now help to suggest mechanistic links. The above also portrays unmethylated regions as being completely passive and remaining unmethylated because there is nothing to recruit DNMT3A/ DNMT3L to these regions (under normal circumstances). Intriguingly, ablation of the protein STELLA (DPPA3, primordial germ cell 7 [PGC7]) leads to pronounced aberrant gain of methylation of intergenic, unmethylated domains ${ }^{50}$, and this depends on UHRF1 and DNMT1. This finding leads to the model in which STELLA is required to prevent nuclear activity of DNMT1/UHRF1 in oocytes (Figure 3). Nevertheless, DNMT1 does seem to be required to fill in the gaps in methylation 

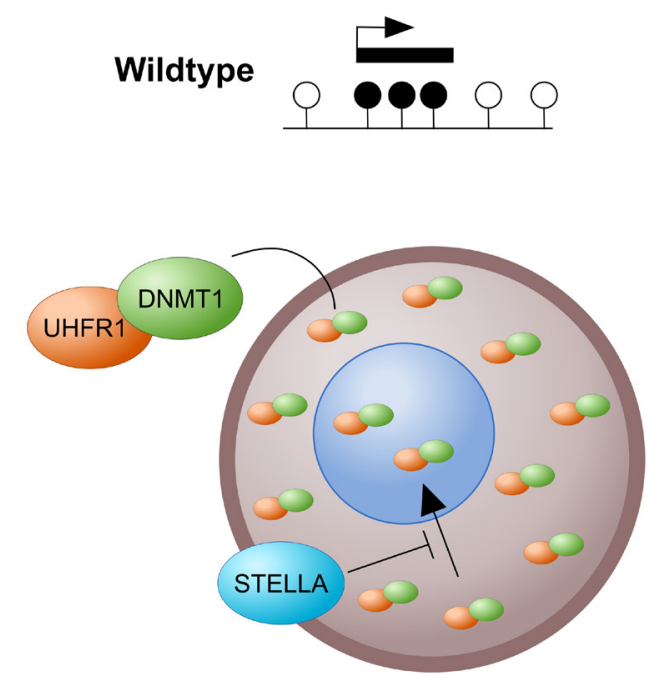
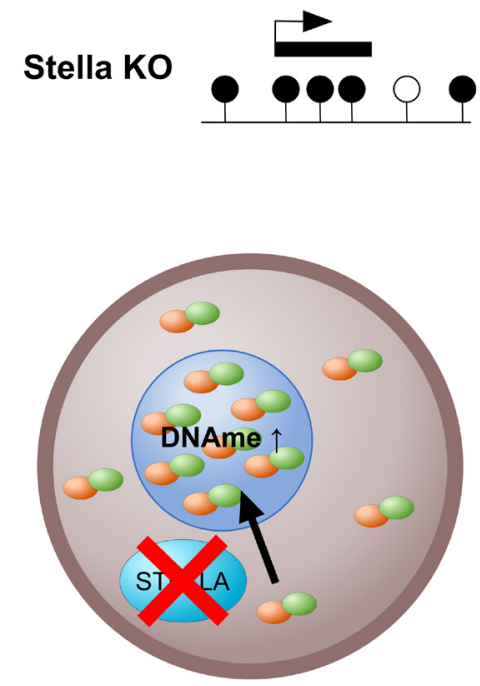

Figure 3. The role of STELLA in regulating methylation in the oocyte. In the oocyte, STELLA is required for the cytoplasmic localisation of the majority of DNA methyltransferase 1 (DNMT1)/ubiquitin-like, plant homeodomain and ring finger-containing 1 (UHRF1). Ablation of STELLA results in UHRF1/DNMT1 redistribution into the nucleus, resulting in increased DNA methylation at regions that are normally unmethylated. $\mathrm{KO}$, knockout.

left by $\mathrm{DNMT}_{3} \mathrm{~A}^{5}$, i.e. to ensure symmetric methylation of CpG sites, thus demonstrating a role for DNMT1 outside of DNA replication (Figure 2A).

\section{DNMT3 paradoxes}

The model above indicates a role for $\mathrm{H} 3 \mathrm{~K} 36 \mathrm{me} 3$ in recruiting DNMT3A to active gene bodies, which was predicted to be mediated via the PWWP domain of $\mathrm{DNMT}^{27}{ }^{27}$. So far, this prediction has not been confirmed. Genomic studies in mouse embryonic stem cells (ESCs) have not identified binding of DNMT3A at H3K36me3-marked domains ${ }^{51}$. Moreover, a point-mutation in the DNMT3A-PWWP domain designed to abrogate the in vitro-defined interaction with H3K36me $3^{27,52}$ does not cause reduced gene-body methylation in oocytes (Sendzikaite and Kelsey, unpublished data). Instead, DNMT3B has been shown to bind and functionally methylate $\mathrm{H} 3 \mathrm{~K} 36 \mathrm{me} 3$ domains in $\mathrm{ESCs}^{51}$, but DNMT3B is functionally insignificant in mouse oocytes ${ }^{5}$. Recently, it was shown that DNMT3A is recruited to sites of H3K36me2 in C3H10T1/2 mesenchymal stem cells $(\mathrm{MSCs})^{53}$. However, the genomic distribution of $\mathrm{H} 3 \mathrm{~K} 36 \mathrm{me} 2$ in oocytes has not been reported, and it is unclear whether it should be restricted to gene bodies, as it was found to have a more diffuse distribution than H3K36me3, encompassing both genic and intergenic regions in MSCs.

Another paradox concerns the role of DNMT3L. In the mouse, ablation of DNMT3L results in failure of de novo methylation in oocytes ${ }^{5,6,13}$. DNMT3L has no catalytic activity, so its requirement indicates an essential role in forming heterotetramers with DNMT3A ${ }^{54}$. However, RNA-seq analysis shows that DNMT3L is not transcribed in human oocytes ${ }^{3}$. Instead, it is possible that DNMT3B substitutes as a partner for
DNMT3A. Intriguingly, it has recently been shown that although DNMT3B is essential for a major portion of the de novo methylation occurring in early post-implantation mouse embryos, this role can largely be provided by a catalytically inactive mutant of DNMT3B ${ }^{55}$. This study supports previous findings from somatic cell lines, also suggesting that catalytically inactive isoforms of DNMT3B can fulfil a structural role as an accessory protein in helping to recruit other DNMTs, similar to DNMT3L ${ }^{56}$. Therefore, it might be that shorter, non-catalytic isoforms of DNMT3B replace DNMT3L in human oocytes as a partner for DNMT3A.

\section{Factors yet to factor in}

In addition to the factors highlighted above-transcription, chromatin, DNA methyltransferases-other molecular or cellular components will be necessary for correctly establishing the DNA methylation pattern distinctive in oocytes. It might be anticipated that factors required to provide the metabolites for de novo methylation-S-adenosylmethionine (SAM) as the universal donor for the methylation reaction, but also other intermediary metabolites such as $\alpha$-ketoglutarate required as a co-factor for lysine demethylases-could be rate-limiting in certain circumstances, such as nutritional deprivation. At this time, there is no real evidence that this is the case, but changes in cellular metabolism have been linked to DNA methylation changes in other contexts. For instance, in somatic cells, mitochondrial depletion has been shown to alter methionine metabolism, resulting in increased SAM levels and consequent increase in DNA methylation ${ }^{57}$. It remains to be seen whether less dramatic, but more pervasive, nutritional imbalances (and their physiological consequences), such as maternal high-fat diet, alter oocyte methylation in a manner that can be 
rationalised by a biochemical mechanism. The availability of quantitative and sensitive methylation profiling methods, including at the single-cell level ${ }^{58}$, should now enable these questions to be asked at a genome-wide level without preconceptions about the types of sequences that could be affected. Moreover, the knowledge of the underlying mechanism of de novo methylation and its relationship to chromatin properties should provide a rational explanation for any effects observed. Finally, the detailed knowledge we also have of how DNA methylation is reprogrammed during preimplantation embryo development should enable us to infer to what extent DNA methylation effects observed in oocytes could influence developmental progression or gene expression in the embryo.

A factor that does have an essential role in DNA methylation, but by still-obscure mechanisms, is the subcortical maternal complex (SCMC). This is a multi-protein complex, whose constituents are abundantly expressed during oocyte growth and which becomes elaborated as a distinct structure under the oocyte plasma membrane ${ }^{59,60}$. It retains this configuration in blastomeres of cleavage embryos. The SCMC is essential for a number of vital processes during the egg-to-embryo transition, such as cellular organisation in the oocyte and mitotic cleavages in the early embryo ${ }^{60}$. Intriguingly, in humans, it also has an impact on the fidelity of DNA methylation in the oocyte and/or preimplantation embryo. This has been indicated by maternal-effect mutations in several components of the SCMC that are associated with imprinting defects or gestational trophoblast diseases ${ }^{61-67}$. Until recently, it was not known whether mutations in these proteins impaired de novo methylation in the oocyte or interfered with DNA methylation maintenance in the cleavage embryo at a time of genome-wide DNA methylation programming during which methylation at imprints has to be maintained. Very recently, using single-cell bisulphite sequencing, we have shown that oocytes with a mutation in the SCMC protein $\mathrm{KH}$ domain containing 3-like (KHDC3L) have severely impaired methylation throughout the genome ${ }^{68}$. Although this is an important advance in knowledge because it identifies the stage at which methylation defects originate, it will be very challenging to elucidate the mechanism by which SCMC defects compromise DNA methylation establishment, given the lack of cellular models to explore these mechanisms in the oocyte. It is unclear whether the murine SCMC is also involved in DNA methylation establishment or imprint maintenance. Mouse knockout models of most of the SCMC proteins result in very early embryo arrest, and analysis has not focused on DNA methylation ${ }^{59,69,70}$. Loss of NLR family pyrin domain containing 2 (NLRP2) was shown to alter the localisation of DNMT1 but not DNMT3A in the oocyte, but only minor and inconsistent changes in the methylation of imprinted genes were observed in embryos or newborn offspring ${ }^{71}$. A closer assessment of mouse SCMC proteins and their role in DNA methylation will be required to determine whether the SCMC has a similar function in mice as in humans and whether mouse knockout models could help to elucidate the mechanism by which it regulates DNA methylation in the oocyte.

\section{Conclusions}

The mammalian oocyte has a deceptively simple DNA methylation landscape that is likely to reflect transcription and associated chromatin remodelling events. Whole-genome sequencing studies assessing DNA methylation, transcription, and histone modifications in combination with gene knockouts in the mouse have supported early hypotheses, but atypical distribution of some histone modifications, as well as unexpected findings in the knockout models, mean that the involvement of some factors remains unclear. In addition to elucidating the factors involved in DNA methylation in the mouse, future studies will also have to link the effect of the unusual transcriptional and epigenetic landscape of the oocyte to the embryo. Furthermore, it has become clear that although the link between transcription and DNA methylation seems to be upheld in human oocytes, other factors, such as the DNMTs and SCMC members, may be differentially regulated in humans.

\section{Abbreviations}

ChIP-seq, chromatin immunoprecipitation and sequencing; DMR, germline differentially methylated region; DNMT, DNA methyltransferase; ERVK, endogenous retrovirus $\mathrm{K}$; ESC, embryonic stem cell; ICR, imprinting control region; H3K4, histone 3 lysine 4; KDM1B/Kdm1b, lysine demethylase 1B; KDM5C, lysine demethylase 5C; LTR: long-terminal repeat; MLL2, mixed lineage leukaemia-2 protein; MSC, mesenchymal stem cell; PHD, plant homeodomain; PRC2, polycomb repressive complex 2; PWWP, Pro-Trp-Trp-Pro motif; SAM, S-adenosylmethionine; SCMC, subcortical maternal complex; UHRF1, ubiquitin-like, PHD and ring finger-containing 1

\section{Acknowledgements}

We would like to thank members of the laboratory for discussion and support.
1. F Greenberg MVC, Bourc'his D: The diverse roles of DNA methylation in mammalian development and disease. Nat Rev Mol Cell Biol. 2019; 20(10): 590-607.

PubMed Abstract | Publisher Full Text | F1000 Recommendation

2. Kobayashi H, Sakurai T, Imai M, et al:: Contribution of intragenic DNA methylation in mouse gametic DNA methylomes to establish oocyte-specific heritable marks. PLoS Genet. 2012; 8(1): e1002440. PubMed Abstract | Publisher Full Text | Free Full Text

3. Okae $\mathrm{H}$, Chiba $\mathrm{H}$, Hiura $\mathrm{H}$, et al:: Genome-wide analysis of DNA methylation dynamics during early human development. PLOS Genet. 2014; 10(12): e1004868. PubMed Abstract | Publisher Full Text | Free Full Text

4. Veselovska L, Smallwood SA, Saadeh H, et al.: Deep sequencing and de novo 
assembly of the mouse oocyte transcriptome define the contribution of transcription to the DNA methylation landscape. Genome Biol. 2015; 16: 209. PubMed Abstract | Publisher Full Text | Free Full Text

5. Shirane $\mathrm{K}$, Toh $\mathrm{H}$, Kobayashi $\mathrm{H}$, et al:: Mouse oocyte methylomes at base resolution reveal genome-wide accumulation of non-CpG methylation and role of DNA methyltransferases. PLOS Genet. 2013; 9(4): e1003439. PubMed Abstract | Publisher Full Text | Free Full Text

6. Smallwood SA, Tomizawa S, Krueger F, et al:: Dynamic CpG island methylation landscape in oocytes and preimplantation embryos. Nat Genet. 2011; 43(8): $811-4$.

PubMed Abstract | Publisher Full Text | Free Full Text

7. F Seisenberger S, Andrews S, Krueger F, et al:: The dynamics of genome-wid DNA methylation reprogramming in mouse primordial germ cells. Mol Cell. 2012; 48(6): 849-62.

PubMed Abstract | Publisher Full Text | Free Full Text | F1000 Recommendation

8. Hanna CW, Demond H, Kelsey G: Epigenetic regulation in development: is the mouse a good model for the human? Hum Reprod Update. 2018; 24(5): 556-76. PubMed Abstract | Publisher Full Text | Free Full Text

9. $\quad \mathrm{F}$ Neri F, Rapelli S, Krepelova A, et al:: Intragenic DNA methylation prevents spurious transcription initiation. Nature. 2017; 543(7643): 72-7. PubMed Abstract | Publisher Full Text | F1000 Recommendation

10. Teissandier A, Bourc'his D: Gene body DNA methylation conspires with H3K36me3 to preclude aberrant transcription. EMBO J. 2017; 36(11): 1471-1473.

PubMed Abstract | Publisher Full Text | Free Full Text

11. Gahurova L, Tomizawa SI, Smallwood SA, et al:: Transcription and chromatin determinants of de novo DNA methylation timing in oocytes. Epigenetics Chromatin. 2017; 10: 25

PubMed Abstract | Publisher Full Text | Free Full Text

12. Ferguson-Smith AC, Surani MA: Imprinting and the epigenetic asymmetry between parental genomes. Science. 2001; 293(5532): 1086-9. PubMed Abstract | Publisher Full Tex

13. F Bourc'his D, Xu GL, Lin CS, et al:: Dnmt3L and the establishment of maternal genomic imprints. Science. 2001; 294(5551): 2536-9. PubMed Abstract | Publisher Full Text | F1000 Recommendation

14. Kaneda M, Hirasawa R, Chiba H, et al:: Genetic evidence for Dnmt3a-dependent imprinting during oocyte growth obtained by conditional knockout with $\mathrm{Zp3}-\mathrm{Cre}$ and complete exclusion of Dnmt3b by chimera formation. Genes Cells. 2010; 15(3): 169-79

PubMed Abstract | Publisher Full Tex

15. Branco MR, King M, Perez-Garcia V, et al:: Maternal DNA Methylation Regulates Early Trophoblast Development. Dev Cell. 2016; 36(2): 152-63. PubMed Abstract | Publisher Full Text | Free Full Text

16. F Chotalia M, Smallwood SA, Ruf N, et al.: Transcription is required for establishment of germline methylation marks at imprinted genes. Genes Dev. 2009; 23(1): 105-17.

PubMed Abstract | Publisher Full Text | Free Full Text | F1000 Recommendation

17. Smith EY, Futtner CR, Chamberlain SJ, et al:: Transcription is required to establish maternal imprinting at the Prader-Willi syndrome and Angelman syndrome locus. PLoS Genet. 2011; 7(12): e1002422. PubMed Abstract | Publisher Full Text | Free Full Text

18. F Singh VB, Sribenja S, Wilson KE, et al:: Blocked transcription through KvDMR1 results in absence of methylation and gene silencing resembling Beckwith-Wiedemann syndrome. Development. 2017; 144(10): 1820-30. PubMed Abstract | Publisher Full Text | Free Full Text | F1000 Recommendation

19. Beygo J, Joksic I, Strom TM, et al.: A maternal deletion upstream of the imprint control region 2 in $11 \mathrm{p} 15$ causes loss of methylation and familia Beckwith-Wiedemann syndrome. Eur J Hum Genet. 2016; 24(9): 1280-6. PubMed Abstract | Publisher Full Text | Free Full Text

20. F Beygo J, Bürger J, Strom TM, et al:: Disruption of KCNQ1 prevents methylation of the ICR2 and supports the hypothesis that its transcription is necessary for imprint establishment. Eur J Hum Genet. 2019; 27(6): 903-8. PubMed Abstract | Publisher Full Text | Free Full Text | F1000 Recommendation

21. F Valente FM, Sparago A, Freschi A, et al.: Transcription alterations of KCNQ1 associated with imprinted methylation defects in the Beckwith-Wiedemann locus. Genet Med. 2019; 21(8): 1808-20.

PubMed Abstract | Publisher Full Text | Free Full Text | F1000 Recommendation

22. F Peaston AE, Evsikov AV, Graber JH, et al:: Retrotransposons regulate host genes in mouse oocytes and preimplantation embryos. Dev Cell. 2004; 7(4): 597-606.

PubMed Abstract | Publisher Full Text | F1000 Recommendation

23. $\mathrm{F}$ Brind'Amour $\mathrm{J}$, Kobayashi $\mathrm{H}$, Richard Albert $\mathrm{J}$, et al.: LTR retrotransposons transcribed in oocytes drive species-specific and heritable changes in DNA methylation. Nat Commun. 2018; 9(1): 3331.

PubMed Abstract | Publisher Full Text | Free Full Text | F1000 Recommendation

24. $F$ Bogutz $A B$, Brind'Amour J, Kobayashi $H$, et al.: Evolution of imprinting via lineage-specific insertion of retroviral promoters. Nat Commun. 2019; 10(1): 5674

PubMed Abstract | Publisher Full Text | Free Full Text | F1000 Recommendation

25. F Ooi SKT, Qiu C, Bernstein E, et al.: DNMT3L connects unmethylated lysine
4 of histone $\mathrm{H3}$ to de novo methylation of DNA. Nature. 2007; 448(7154): 714-7. PubMed Abstract | Publisher Full Text | Free Full Text | F1000 Recommendation

26. $\mathrm{F}$ Guo $X$, Wang L, Li J, et al.: Structural insight into autoinhibition and histone H3-induced activation of DNMT3A. Nature. 2015; 517(7536): 640-4. PubMed Abstract | Publisher Full Text | F1000 Recommendation

27. Dhayalan A, Rajavelu A, Rathert $P$, et al:: The Dnmt3a PWWP domain reads histone 3 lysine 36 trimethylation and guides DNA methylation. $J$ Biol Chem. 2010; 285(34): 26114-20.

PubMed Abstract | Publisher Full Text | Free Full Text

28. F Heyn P, Logan CV, Fluteau A, et al:: Gain-of-function DNMT3A mutations cause microcephalic dwarfism and hypermethylation of Polycomb-regulated regions. Nat Genet. 2019; 51(1): 96-105.

PubMed Abstract | Publisher Full Text | Free Full Text | F1000 Recommendation

29. $\mathrm{F}$ Manzo M, Wirz J, Ambrosi C, et al:: Isoform-specific localization of DNMT3A regulates DNA methylation fidelity at bivalent CpG islands. EMBO J.2017; 36(23): 3421-34.

PubMed Abstract | Publisher Full Text | Free Full Text | F1000 Recommendation

30. $\mathrm{F}$ Gu T, Lin X, Cullen SM, et al:: DNMT3A and TET1 cooperate to regulate promoter epigenetic landscapes in mouse embryonic stem cells. Genome Biol. 2018; 19(1): 88.

PubMed Abstract | Publisher Full Text | Free Full Text | F1000 Recommendation

31. Kelsey G, Feil R: New insights into establishment and maintenance of DNA methylation imprints in mammals. Philos Trans $R$ Soc Lond B Biol Sci. 2013; 368(1609): 20110336.

PubMed Abstract | Publisher Full Text | Free Full Text

32. F Dahl JA, Jung I, Aanes $\mathrm{H}$, et al.: Broad histone H3K4me3 domains in mouse oocytes modulate maternal-to-zygotic transition. Nature. 2016; 537(7621): $548-52$.

PubMed Abstract | Publisher Full Text | Free Full Text | F1000 Recommendation

33. $\mathrm{F}$ Zhang $\mathrm{B}$, Zheng $\mathrm{H}$, Huang $\mathrm{B}$, et al:: Allelic reprogramming of the histone modification H3K4me3 in early mammalian development. Nature. 2016; 537(7621): 553-7.

PubMed Abstract | Publisher Full Text | F1000 Recommendation

34. Hanna CW, Taudt A, Huang J, et al.: MLL2 conveys transcription-independent H3K4 trimethylation in oocytes. Nat Struct Mol Biol. 2018; 25(1): 73-82.

PubMed Abstract | Publisher Full Text

35. $\mathrm{F} X u \mathrm{Q}, \mathrm{Xiang} \mathrm{Y}$, Wang $\mathrm{Q}$, et al.: SETD2 regulates the maternal epigenome, genomic imprinting and embryonic development. Nat Genet. 2019; 51(5): $844-56$.

PubMed Abstract | Publisher Full Text | F1000 Recommendation

36. Stewart KR, Veselovska L, Kim J, et al.: Dynamic changes in histone modifications precede de novo DNA methylation in oocytes. Genes Dev. 2015; 29(23): 2449-62.

PubMed Abstract | Publisher Full Text | Free Full Text

37. F Ciccone DN, Su H, Hevi S, et al:: KDM1B is a histone H3K4 demethylase required to establish maternal genomic imprints. Nature. 2009; 461(7262) 415-8.

PubMed Abstract | Publisher Full Text | F1000 Recommendation

38. Nashun B, Hill PW, Smallwood SA, et al:: Continuous Histone Replacement by Hira Is Essential for Normal Transcriptional Regulation and De Novo DNA Methylation during Mouse Oogenesis. Mol Cell. 2015; 60(4): 611-25.

PubMed Abstract | Publisher Full Text | Free Full Text

39. Zheng H, Huang B, Zhang B, et al.: Resetting Epigenetic Memory by Reprogramming of Histone Modifications in Mammals. Mol Cell. 2016; 63(6) 1066-79.

PubMed Abstract | Publisher Full Text

40. Inoue A, Chen Z, Yin Q, et al:: Maternal Eed knockout causes loss of H3K27me3 imprinting and random $\mathbf{X}$ inactivation in the extraembryonic cells. Genes Dev. 2018; 32(23-24): 1525-36.

PubMed Abstract | Publisher Full Text | Free Full Text

41. Prokopuk L, Stringer JM, White CR, et al: Loss of maternal EED results in postnatal overgrowth. Clin Epigenetics. 2018; 10(1): 95 PubMed Abstract | Publisher Full Text | Free Full Text

42. Ragazzini R, Pérez-Palacios R, Baymaz IH, et al.: EZHIP constrains Polycomb Repressive Complex 2 activity in germ cells. Nat Commun. 2019; 10(1): 3858. PubMed Abstract | Publisher Full Text | Free Full Text

43. F Au Yeung WK, Brind'Amour J, Hatano Y, et al:: Histone H3K9 Methyltransferase G9a in Oocytes Is Essential for Preimplantation Development but Dispensable for CG Methylation Protection. Cell Rep. 2019; 27(1): 282-293.e4.

PubMed Abstract | Publisher Full Text | F1000 Recommendation

44. F Wang C, Liu X, Gao Y, et al.: Reprogramming of H3K9me3-dependent heterochromatin during mammalian embryo development. Nat Cell Biol. 2018; 20(5): 620-31.

PubMed Abstract | Publisher Full Text | F1000 Recommendation

45. Nady N, Lemak A, Walker JR, et al.: Recognition of multivalent histone states associated with heterochromatin by UHRF1 protein. J Biol Chem. 2011; 286(27): 24300-11.

PubMed Abstract | Publisher Full Text | Free Full Text

46. Arita K, Isogai S, Oda T, et al:: Recognition of modification status on a histone 
H3 tail by linked histone reader modules of the epigenetic regulator UHRF1. Proc Natl Acad Sci U S A. 2012; 109(32): 12950-5.

PubMed Abstract | Publisher Full Text | Free Full Text

47. Rothbart SB, Krajewski K, Nady N, et al:: Association of UHRF1 with methylated H3K9 directs the maintenance of DNA methylation. Nat Struct Mol Biol. 2012; 19(11): 1155-60.

PubMed Abstract | Publisher Full Text | Free Full Text

48. Rothbart SB, Dickson BM, Ong MS, et al.: Multivalent histone engagement by the linked tandem Tudor and PHD domains of UHRF1 is required for the epigenetic inheritance of DNA methylation. Genes Dev. 2013; 27(11): 1288-98. PubMed Abstract | Publisher Full Text | Free Full Text

49. $\mathrm{F}$ Maenohara S, Unoki M, Toh $\mathrm{H}$, et al.: Role of UHRF1 in de novo DNA methylation in oocytes and maintenance methylation in preimplantation embryos. PLoS Genet. 2017; 13(10): e1007042.

PubMed Abstract | Publisher Full Text | Free Full Text | F1000 Recommendation

50. F Li Y, Zhang Z, Chen J, et al.: Stella safeguards the oocyte methylome by preventing de novo methylation mediated by DNMT1. Nature. 2018; 564(7734): 136-40.

PubMed Abstract | Publisher Full Text | F1000 Recommendation

51. Baubec T, Colombo DF, Wirbelauer C, et al.: Genomic profiling of DNA methyltransferases reveals a role for DNMT3B in genic methylation. Nature. 2015; 520(7546): 243-7.

PubMed Abstract | Publisher Full Text

52. Sendžikaitè G, Hanna CW, Stewart-Morgan KR, et al:: A DNMT3A PWWP mutation leads to methylation of bivalent chromatin and growth retardation in mice. Nat Commun. 2019; 10(1): 1884. PubMed Abstract | Publisher Full Text | Free Full Text

53. F Weinberg DN, Papillon-Cavanagh $\mathrm{S}$, Chen $\mathrm{H}$, et al:: The histone mark H3K36me2 recruits DNMT3A and shapes the intergenic DNA methylation landscape. Nature. 2019; 573(7773): 281-6.

PubMed Abstract | Publisher Full Text | Free Full Text | F1000 Recommendation

54. F Jia D, Jurkowska RZ, Zhang X, et al:: Structure of Dnmt3a bound to Dnmt3L suggests a model for de novo DNA methylation. Nature. 2007; 449(7159): 248-51.

PubMed Abstract | Publisher Full Text | Free Full Text | F1000 Recommendation

55. F Nowialis P, Lopusna K, Opavska J, et al:: Catalytically inactive Dnmt3b rescues mouse embryonic development by accessory and repressive functions. Nat Commun. 2019; 10(1): 4374.

PubMed Abstract | Publisher Full Text | Free Full Text | F1000 Recommendation

56. Duymich CE, Charlet J, Yang X, et al.: DNMT3B isoforms without catalytic activity stimulate gene body methylation as accessory proteins in somatic cells. Nat Commun. 2016; 7: 11453.

PubMed Abstract | Publisher Full Text | Free Full Text

57. F Lozoya OA, Martinez-Reyes I, Wang T, et al:: Mitochondrial nicotinamide adenine dinucleotide reduced (NADH) oxidation links the tricarboxylic acid (TCA) cycle with methionine metabolism and nuclear DNA methylation. PLOS Biol. 2018; 16(4): e2005707.

PubMed Abstract | Publisher Full Text | Free Full Text | F1000 Recommendation

58. F Kelsey G, Stegle O, Reik W: Single-cell epigenomics: Recording the past and predicting the future. Science. 2017; 358(6359): 69-75 PubMed Abstract | Publisher Full Text | F1000 Recommendation

59. Li L, Baibakov B, Dean J: A Subcortical Maternal Complex Essential for Preimplantation Mouse Embryogenesis. Dev Cell. 2008; 15(3): 416-25. PubMed Abstract | Publisher Full Text | Free Full Text

60. F Lu X, Gao Z, Qin D, et al:: A Maternal Functional Module in the Mammalian Oocyte-To-Embryo Transition. Trends Mol Med. 2017; 23(11): 1014-23. PubMed Abstract | Publisher Full Text | F1000 Recommendation

61. Murdoch S, Djuric U, Mazhar B, et al.: Mutations in NALP7 cause recurrent hydatidiform moles and reproductive wastage in humans. Nat Genet. 2006; 38(3): 300-2.

PubMed Abstract | Publisher Full Text

62. Parry DA, Logan CV, Hayward BE, et al.: Mutations causing familial biparental hydatidiform mole implicate c6orf221 as a possible regulator of genomic imprinting in the human oocyte. Am J Hum Genet. 2011; 89(3): 451-8. PubMed Abstract | Publisher Full Text | Free Full Text

63. Docherty LE, Rezwan FI, Poole RL, et al: Mutations in NLRP5 are associated with reproductive wastage and multilocus imprinting disorders in humans. Nat Commun. 2015; 6: 8086.

PubMed Abstract | Publisher Full Text | Free Full Text

64. Alazami AM, Awad SM, Coskun S, et al: TLE6 mutation causes the earliest known human embryonic lethality. Genome Biol. 2015; 16: 240. PubMed Abstract | Publisher Full Text | Free Full Text

65. Xu Y, Shi Y, Fu J, et al:: Mutations in PADI6 Cause Female Infertility Characterized by Early Embryonic Arrest. Am J Hum Genet. 2016; 99(3): 744-52.

PubMed Abstract | Publisher Full Text | Free Full Text

66. F Begemann M, Rezwan FI, Beygo J, et al:: Maternal variants in NLRP and other maternal effect proteins are associated with multilocus imprinting disturbance in offspring. $J$ Med Genet. 2018; 55(7): 497-504.

PubMed Abstract | Publisher Full Text | Free Full Text | F1000 Recommendation

67. F Mu J, Wang W, Chen B, et al:: Mutations in NLRP2 and NLRP5 cause female infertility characterised by early embryonic arrest. J Med Genet. 2019; 56(7): 471-80. PubMed Abstract | Publisher Full Text | F1000 Recommendation

68. Demond $\mathrm{H}$, Anvar Z, Jahromi BN, et al:: A KHDC3L mutation resulting in recurrent hydatidiform mole causes genome-wide DNA methylation loss in oocytes and persistent imprinting defects post-fertilisation. Genome Med. 2019; 11(1): 84 . PubMed Abstract | Publisher Full Text | Free Full Text

69. Tong ZB, Gold L, Pfeifer KE, et al:: Mater, a maternal effect gene required for early embryonic development in mice. Nat Genet. 2000; 26(3): 267-8. PubMed Abstract | Publisher Full Text

70. Yu XJ, Yi Z, Gao Z, et al:: The subcortical maternal complex controls symmetric division of mouse zygotes by regulating F-actin dynamics. Nat Commun. 2014; 5: 4887.

PubMed Abstract | Publisher Full Text | Free Full Text

71. F Mahadevan S, Sathappan V, Utama B, et al.: Maternally expressed NLRP2 links the subcortical maternal complex (SCMC) to fertility, embryogenesis and epigenetic reprogramming. Sci Rep. 2017; 7: 44667.

PubMed Abstract | Publisher Full Text | Free Full Text | F1000 Recommendation 


\section{Open Peer Review}

\section{Current Peer Review Status:}

\section{Editorial Note on the Review Process}

Faculty Reviews are review articles written by the prestigious Members of Faculty Opinions. The articles are commissioned and peer reviewed before publication to ensure that the final, published version is comprehensive and accessible. The reviewers who approved the final version are listed with their names and affiliations.

\section{The reviewers who approved this article are:}

\section{Version 1}

1. Wei Xie

School of Life Sciences, Tsinghua University, Beijing, China

Competing Interests: No competing interests were disclosed.

\section{Taiping Chen}

Department of Epigenetics and Molecular Carcinogenesis, The University of Texas MD Anderson Cancer Center, Smithville, TX, USA

Competing Interests: No competing interests were disclosed.

\section{Hiroyuki Sasaki}

Division of Epigenomics and Development, Medical Institute of Bioregulation, Kyushu University,

Fukuoka, Japan

Competing Interests: No competing interests were disclosed.

\section{Matthew Lorincz}

Department of Medical Genetics, Life Sciences Institute, University of British Columbia, Vancouver, BC, Canada

Competing Interests: No competing interests were disclosed. 
The benefits of publishing with F1000Research:

- Your article is published within days, with no editorial bias

- You can publish traditional articles, null/negative results, case reports, data notes and more

- The peer review process is transparent and collaborative

- Your article is indexed in PubMed after passing peer review

- Dedicated customer support at every stage

For pre-submission enquiries, contact research@f1000.com 